УДК 676.026 .54

DOI: https://doi.org/10.26642/ten-2019-2(84)-51-55

\author{
І.І. Холод, магістрант \\ Я.В. Гробовенко, асистент \\ Національний технічний університет Украӥни \\ «Київський політехнічний інститут імені Ігоря Сікорського»
}

\title{
Моделювання процесу охолодження картонного полотна
}

\author{
(Представлено: д.т.н., проф. Корнієнко Я.М.)
}

\begin{abstract}
Ефективне охолодження картонного полотна впливає на його техніко-технологічні показники та металомісткість холодильної частини. Проведено огляд сучасних конструкиій холодильних частин і циліндрів та вибрано найбільш оптимальну конструкиію холодильного ичліндра. Проведення теплообмінних процесів у технології виготовлення целюлозно-паперової продукції при отриманні картону є одним з найбільш прогресивних підходів. Холодильна частина картоноробної машини відіграє важливу роль в технології отримання якісної картонної продукиї. Охолодження картонного полотна дозволяе зробити його достатньо м'яким та еластичним і придатним для каландрування, а також запобігає електризації сухого картону під час тертя. Як холодоагент автори статті пропонують використовувати холодну воду, щуо $\epsilon$ досить дешевим теплоносієм. Стандартна конструкиія холодильного ичиліндра передбачає, щзо холодоагент подається в середину холодильного ичиліндра $і$ розподіляться по периферіі внутрішньої поверхні, а відпрацьований холодоагент відбирається з бічних сторін ииліндра. Для збільшення швидкості прочесу охолодження картонного полотна авторами запропоновано встановити повітряні сприски над зоною контакту полотна і поверхні холодильного цииліндра. Це дозволить додатково охолодити зовнішню поверхню полотна, щуо не контактує із поверхнею цุиліндра, а також створити додаткове притискання полотна до оболонки поверхні цүиліндра. Створено $3 D$ модель холодильної частини картоноробної машини. Здійснено імітаційне моделювання процесу охолодження картонного полотна із використанням системи моделювання SolidWorks та визначено зміну температури по товщині полотна. Визначено оптимальні температурні режими прочесу охолодження полотна та отримано залежність зміни температури картону від його товщини.
\end{abstract}

Ключові слова: процес охолодження; картонне полотно; моделювання; температурне поле; швидкість охолодження.

Актуальність теми. Холодильна частина картоноробної машини відіграє важливу роль у технології отримання якісної картонної продукції. Охолодження картонного полотна дозволяє зробить його достатньо м'яким та еластичним і придатним для каландрування, а також запобігає електризації сухих волокон картону під час тертя [1]. Процес охолодження відбувається на холодильній групі циліндрів, що розміщена в кінці сушильної частини картоноробної машини. Зазвичай як холодоагент використовується холодна вода [2]. Ефективність процесу охолодження картону залежить від температурного режиму холодоагенту, конструкції холодильного циліндра та шорсткості його зовнішньої циліндричної поверхні. Тому моделювання процесу охолодження картонного полотна для визначення оптимальних параметрів кінетики охолодження, що забезпечують зменшення затрат на проведення цього процесу, є актуальним завданням.

Аналіз останніх досліджень та публікації, на які спирається автор. Зокрема, сучасні оптимальні конструкції холодильних циліндрів представлені компанією «Valmet» [3]. Визначення коефіцієнта теплопередачі та енергозатрат на процес охолодження проводили Mr L.Suomalainen i Ms H.Hyytia [4], W.Martz i M.Soucy [5]. Розрахунок кінетичних параметрів процесу охолодження картонного полотна проводили Б.В. Акулов і С.Г. Срмак [6].

Метою статті $\mathbf{\epsilon}$ визначення кінетичних закономірностей та основних параметрів процесу охолодження картонного полотна, що необхідні для інтенсифікації процесу та розробки промислового холодильного обладнання.

Викладення основного матеріалу. Аналіз сучасних конструкцій холодильних конструкцій показав, що стандартна конструкція холодильного циліндра передбачає, що холодоагент подається в середину холодильного циліндра і розподіляється по периферії внутрішньої поверхні (рис. 1), а відпрацьований холодоагент відбирається з бічних сторін циліндра [2].

(C) І.І. Холод, Я.В. Гробовенко, 2019 


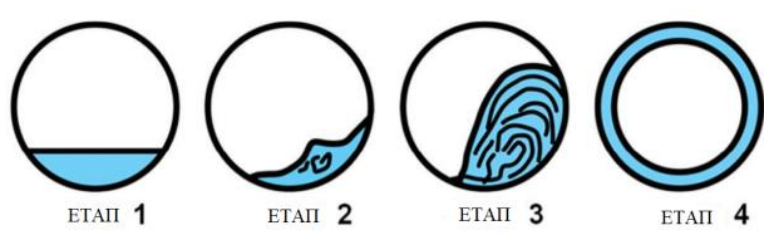

Рис. 1. Схема розподіленя холодної води в середині холодильного циліндра

Рисунок 1 ілюструє чотири основні етапи розподілення води при зміні швидкості обертання холодильного циліндра:

- етап 1 - відсутність обертання. Вода рівномірно розподіляється в нижній частині циліндра;

- етап 2 - калюжа. Коли циліндр починає обертатися, калюжа рухається вгору разом із оболонкою циліндра;

- етап 3 - каскад. Більш інтенсивне обертання холодильного циліндра змушує калюжу рухатися далі вгору до корпусу доки сила тяжіння не подолає відцентрові сили і вода знову повернеться на дно оболонки;

- етап 4 - водяне кільце. Із виходом циліндра на робочу швидкість обертання відцентрові сили долають силу тяжіння так, що утворюється рівномірний шар води по внутрішньому діаметру оболонки.

Важливим фактором у конструкціях холодильних циліндрів являється шорсткість їх поверхні, оскільки від цього залежить інтенсивність тепловіддачі від поверхні циліндра до картонного полотна. У зв'язку із цим поверхні холодильних циліндрів покривають шаром гладкого матеріалу, наприклад, хрому. Крім цього, інтенсивність охолодження картонного полотна залежить від способу подачі холодної води в порожнину циліндра, а також відведення вже нагрітої води. Конструкцію холодильного циліндра із системами подачі і відведення холодоагенту зображено на рисунку 2.

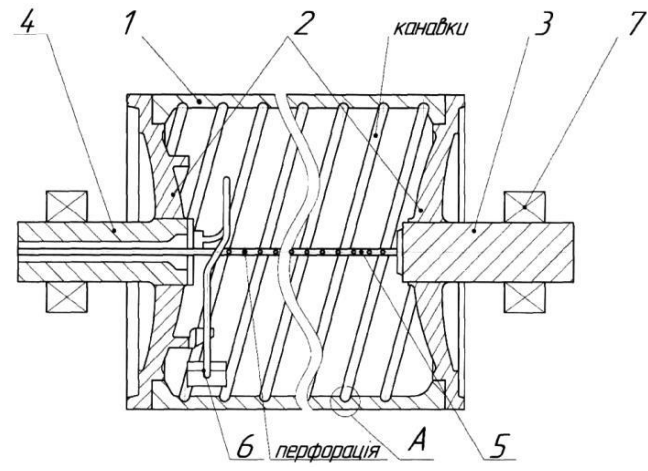

Рис. 2. Удосконалена конструкиія холодильного ичиліндра

(1-оболонка циліндра; 2 - кришка; 3 - привідна циапфа; 4 - иапфа із каналами для подачі $i$ відведення холодоагенту; 5 - перфорована трубка; 6 - черпак; 7 - підиипник)

Холодильний циліндр працює таким чином: попередньо висушене та нагріте полотно потрапляє на зовнішню поверхню холодильного циліндра 1 , що обертається. Холодоагент через перфоровану трубку 5 , яка направлена отворами на внутрішню поверхню холодильного циліндра 1 , подається під тиском в його внутрішню порожнину. На внутрішній поверхні циліндра утворюється шар холодоагенту, що відкачується черпаком 6 назовні. Під час потрапляння в канавки холодоагент збільшує свою турбулентність, а напрямок нарізки частково спрямовує потік холодоагенту до черпака, полегшуючи його відведення.

Процес охолодження відбувається в холодильній групі циліндрів (рис. 3, б), що розміщена в кінці сушильної частини картоноробної машини. Для збільшення швидкості процесу охолодження картонного полотна пропонується встановити повітряні сприски над зоною контакту полотна і поверхні циліндра [8]. Це дозволить додатково охолодити зовнішню поверхню полотна, що не контактує із поверхнею циліндра, а також з'являється додаткове притискання полотна до оболонки поверхні циліндра. Схема теплообміну в цьому випадку між полотном і холодоагентом зображена на рисунку $3, a$. 


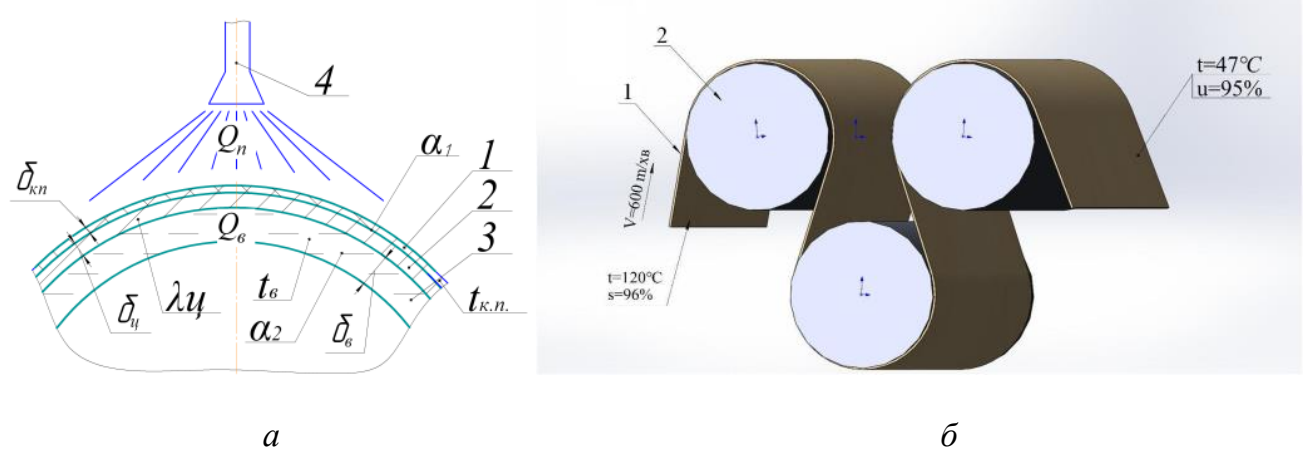

Рис. 3. Схема охолодження картонного полотна: а) схема теплообміну; б) холодильна група циилндрів; 1 - полотно; 2 -металева стінка цииліндра; 3 - холодоагент (холодна вода); 4 - повітряний сприск

Конструкція холодильного циліндра передбачає, що тепловий потік направлений від гарячого полотна через стінку циліндра до холодоагенту:

$$
\mathrm{Q}=\mathrm{K} \cdot \mathrm{F} \cdot \Delta \mathrm{T} \text {, }
$$

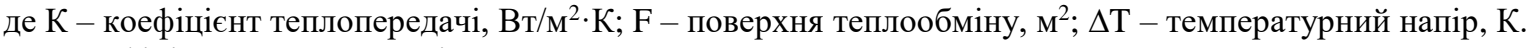

Коефіцієнт теплопередачі у цьому випадку визначається як:

$$
K=\frac{1}{\frac{1}{\alpha_{1}}+\frac{\delta_{\ddot{o}}}{\lambda_{\ddot{o}}}+\frac{1}{\alpha_{2}}},
$$

де $\alpha_{1}-$ коефіціснт тепловіддачі від поверхні полотна до зовнішньої поверхні холодильного циліндра, $\mathrm{B} / \mathrm{M}^{2} \cdot \mathrm{K} ; \delta_{\text {щ }}-$ товщина оболонки циліндра, м; $\lambda_{\Perp}-$ теплопровідність матеріалу оболонки циліндра, Вт/м·К; $\alpha_{2}$ - коефіцієнт тепловіддачі від внутрішньої поверхні оболонки циліндра, Вт $/ \mathrm{M}^{2} \cdot \mathrm{K}$.

Дослідження теплообміну при охолодженні картонного або паперового полотна [7] показали, що коефіцієнт $\alpha_{1}$ приймає достатньо малі значення $5-10 \mathrm{BT} / \mathrm{M}^{2} \cdot \mathrm{K}$ і залежить від шорсткості поверхні оболонки холодильного циліндра. Внаслідок цього для підвищення ефективності процесу охолодження полотна необхідно збільшити тепловий потік $\mathrm{Q}$, кВт від полотна до холодоагенту. Для вирішення цього завдання пропонується встановити для додаткового охолодження полотна повітряний сприск (рис. $3, a$ ). Тому результуючий тепловий потік становитиме:

$$
\mathrm{Q}=\mathrm{Q}_{1}+\mathrm{Q}_{2} \text {, }
$$

де $\mathrm{Q}_{1}$ - тепловий потік від полотна до холодної води, кВт; $\mathrm{Q}_{2}$ - тепловий потік від полотна до холодного повітря, кВт.

За допомогою програми автоматизованого проектування і моделювання SolidWorks Simulation 2019 та модуля Flow Simulation проведено моделювання теплообміну елементарної частинки картонного полотна $\mathrm{dF}$ при таких початкових параметрах:

- матеріал - картон (матеріал доданий користувачем);

- тип задачі - зовнішня;

- межові умови для сторони картонного полотна, що контактує із поверхнею холодильного циліндру встановлені, як «Real Wall» із температурою 283 K;

- межові умови для сторона полотна, що контактує із повітрям встановлені, як «Outer Wall» із температурою 313 К (приймаємо, що температура навколишнього середовища в зоні охолодження $40 \mathrm{C})$;

- початкові умови: фізичний час становить 0,21 с (4); шорсткість стінок - 10 мкм; тиск атмосферний; температура картонного полотна - 393 К; температура поверхні холодильного циліндра 283 К; товщина картонного полотна - 1 мм.

Фізичний час контакту картонного полотна розраховується як:

$$
\tau=\frac{\pi D \xi}{2 \times W}=\frac{3,14 \times 1,5 \times 0,7}{2 \times 8,3}=0,21 c,
$$

де $D$ - діаметр холодильного циліндра; $W$ - швидкість руху картонного полотна; $\xi$ - коефіцієнт обхвату картонним полотном поверхні холодильного циліндра.

Швидкість обертання оболонки холодильного циліндра визначається: 


$$
n=\frac{W}{\pi D}=\frac{8,3}{3,14 \times 1,5}=1,76\left[\frac{\hat{\imath} a ́}{c}\right] .
$$

Результат розрахунку представляє епюру розподілу температури по товщині полотна (рис. 4).

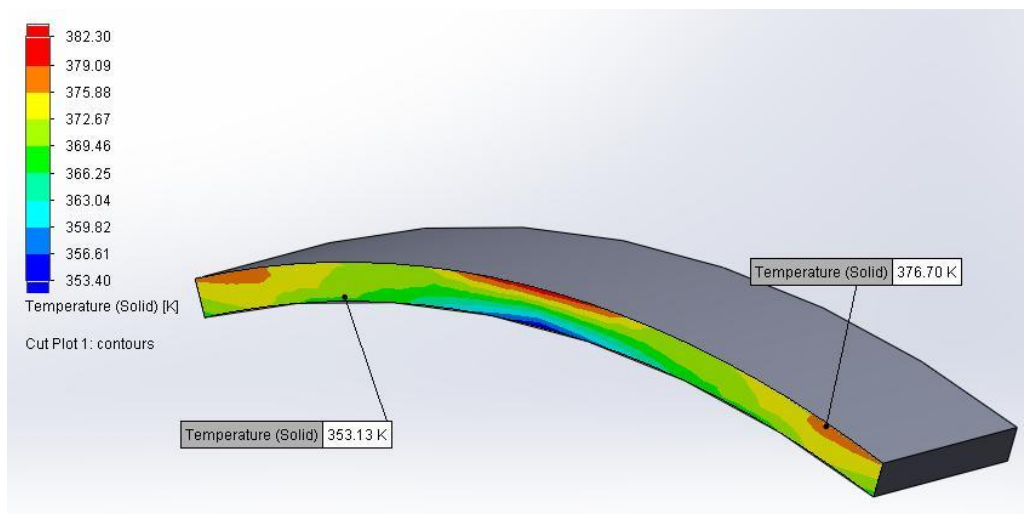

Рис. 4. Зміна температури полотна матеріалу по його товщчині

Як видно із рисунка 4, температура картонного полотна змінюється від максимального значення в зоні поверхні, яка контактує із повітрям і становить 382,3 К до мінімальної температури картону, що становить 353,4 К в зоні контакту із поверхнею холодильного циліндра із температурою 283 К.

Графік розподілу температури полотна $\mathrm{T}, \mathrm{K}$ по його товщині $\delta$, мм та рівняння лінії тренда зображено на рисунку 5.

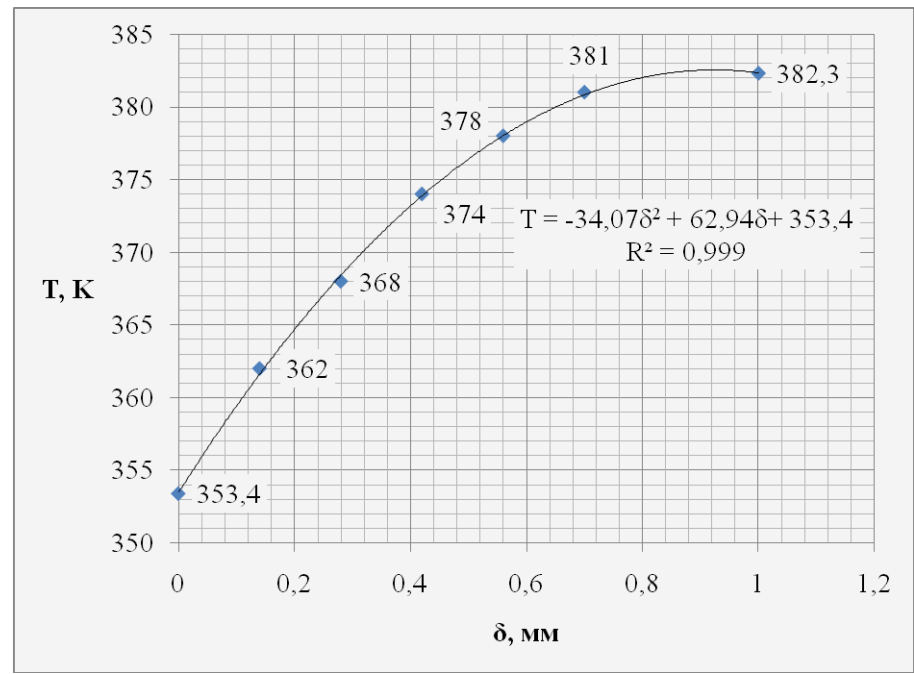

Рис. 5. Графічна залежність зміни температури полотна по його товщині

Апроксимація температурних точок по товщині полотна дозволяє отримати рівняння лінії тренда, що характеризує залежність $T=f(\delta)$ :

$$
\mathrm{T}=-34,07 \delta^{2}+62,94 \delta+353,4 \text {. }
$$

Аналіз залежності на рисунку 5 показує, що картонне полотно за час контакту із поверхнею одного холодильного циліндра охолоджується від початкової температури $393 \mathrm{~K}$ до середньої

$$
\mathrm{T}=(382,3+353,4) / 2=367,8 \mathrm{~K} \text {, тобто на } 25,2 \mathrm{~K} \text {. }
$$

Висновки та перспективи подальших досліджень. Запропоновано модель імітаційного моделювання процесу охолодження картонного полотна із використанням системи автоматизації проектування SilodWorks та визначено оптимальні кінетичні параметри процесу, що дозволяють зменшити енергозатрати на проведення процесу охолодження картонного полотна, зокрема:

1) початкова температура холодоносія, як і поверхня холодильного циліндра, має бути не вище 283 К;

2) початкова температура картонного полотна, яке поступає на холодильну частину картоноробної машини, - $393 \mathrm{~K}$;

3) поверхня холодильного циліндра має бути відполірованою із шорсткістю не більше 10 мкм; 
4) температура навколишнього середовища в зоні холодильної частини - не більше 313 К.

Крім того, отримано епюру і визначено поле розподілу температури по товщині картонного полотна та знайдено середню його температуру після контакту із одним холодильним циліндром, що дорівнює 367,8 К. Спрямування подальших досліджень полягає у практичному впровадженні результатів роботи, створенні математичної моделі процесу охолодження та перевірці їі адекватності експериментальним шляхом.

\section{Список використаної літератури:}

1. Чичаєв А.А. Обладнання целюлозно-паперового виробництва» в двох томах. Т. 2: Папероробні машини / A.А. Чичаєв. - М. : Лісова Промисловість, 1981. - 264 с.

2. Новиков Н.Е. Прессование бумажного полотна / Н.Е. Новиков - М. : Лесная промышленность, 1972. -240 с.

3. Stream and condensate system improvements [Електронний pecypc].- Режим доступу : https://www.valmet.com/globalassets/media/downloads/white-papers/drying-and-airsystems/wpd_steamcondensate.pdf.

4. Suomalainen L. Energy efficiency in steam and condensate savings / L.Suomalainen, H.Hyytia // Study of energy efficiency in industry. - 2012. - № 1. - P. 617-622.

5. Martz W. Framework for optimization of the paper machine dryer section / W.Martz, M.Soucy // The Johnson Canada Corporation. - 2014. - № 1. - P. 136-141.

6. Акулов Б.В. Производство бумаги и картона / Б.В. Акулов, С.Г. Ермаков. - Издательство Пермского государственного технического университета, 2010. - $440 \mathrm{c}$.

7. Kyoung Suk Thermal Flow Analysis of Vehicle Engine Cooling System // Kyoung Suk, Jong Phil, Hyung Seok. KSME International Journal. - 2002. - Vol. 16, № 7. - P. 975-985.

8. Abhishek S. Advance Engine Cooling System // S.Abhishek, K.Singh, M.Sudhanshu // International Journal of Advanced Technology \& Engineering Research. - 2014. - № 1. - P. 346-357.

9. Paper mill upgrades air dryer and cooling system [Електронний ресурс]. - Режим доступу : https://www.airbestpractices.com/technology/cooling-systems/paper-mill-upgrades-air-dryer-and-cooling-systemf.

10. Cooling system [Електронний ресурс]. - Режим доступу : https://www.britannica.com/technology/cooling-system.

\section{References:}

1. Chychajev, A.A. (1981), Obladnannja celjulozno-paperovogo vyrobnyctva» v dvoh tomah. T. 2: Paperorobni mashyny, Lisova Promyslovist', M., 264 p.

2. Novikov, N.E. (1972), Pressovanie bumazhnogo polotna, Lesnaja promyshlennost', M., 240 p.

3. Stream and condensate system improvements, [Online], available at: https://www.valmet.com/globalassets/media/downloads/white-papers/drying-and-air-

systems/wpd_steamcondensate.pdf

4. Suomalainen, L. and Hyytia, H. (2012), «Energy efficiency in steam and condensate savings», Study of energy efficiency in industry, No. 1, pp. 617-622.

5. Martz, W. and Soucy, M. (2014), «Framework for optimization of the paper machine dryer section», The Johnson Canada Corporation, No. 1, pp. 136-141.

6. Akulov, B.V. and Ermakov, S.G. (2010), Proizvodstvo bumagi i kartona, Izdatel'stvo Permskogo gosudarstvennogo tehnicheskogo universiteta, $440 \mathrm{p}$.

7. Kyoung Suk, Jong Phil and Hyung Seok (2002), «Thermal Flow Analysis of Vehicle Engine Cooling System», KSME International Journal, Vol. 16, No. 7, pp. 975-985.

8. Abhishek, S., Singh, K. and Sudhanshu, M. (2014), «Advance Engine Cooling System», International Journal of Advanced Technology \& Engineering Research, No. 1, pp. 346-357.

9. Paper mill upgrades air dryer and cooling system, [Online], available at: https://www.airbestpractices.com/technology/cooling-systems/paper-mill-upgrades-air-dryer-and-cooling-systemf

10. Cooling system, [Online], available at: https://www.britannica.com/technology/cooling-system

Холод Ігор Іванович - магістрант кафедри машин та апаратів хімічних та нафтопереробних виробництв Національного технічного університету України «Київський політехнічний інститут імені Ігоря Сікорського».

Наукові інтереси:

- теплообмінні процеси в технології виробництва целюлозно-паперової продукції.

Гробовенко Ярослав Віталійович - асистент кафедри машин та апаратів хімічних та нафтопереробних виробництв Національного технічного університету України «Київський політехнічний інститут імені Ігоря Сікорського».

E-mail: ygrobovenko@gmail.com.

Наукові інтереси:

- процеси тепломасообміну в системах «тверде тіло - рідина», «тверде тіло - газ», що відбуваються в псевдозрідженому шарі. 